UOT 661.099 .2

\title{
PREPARATION AND RESEARCH INTO FUNCTIONAL PROPERTIES OF NANOSTRUCTURED TITANATES OF LITHIUM AND SODIUM
}

\author{
A.N. Mammadov ${ }^{1,2}$, U.N. Sharifova ${ }^{2}$, G.M. Samedzade ${ }^{1}$, G.A.Pashazade ${ }^{1}$, S.A.Guliyeva ${ }^{3}$ \\ ${ }^{1}$ Acad. M. Nagiyev Institute of Catalysis and Inorganic Chemistry ANAS \\ 113, H.Javid ave., AZ 1134, Baku e-mail: asif.mammadov.47@mail.ru \\ ${ }^{2}$ Azerbaijan Technical University \\ 25, H. Javid ave, AZ-1073 Baku \\ ${ }^{3}$ Azerbaijan State Pedagogical University \\ U. Hacibeyli str.68, AZ 1000, Baku
}

Received 26.03.2019

\begin{abstract}
Information about methods of preparation, structure and physical-chemical properties of nanostructured materials based on lithium and sodium titanates was analyzed and summarized. The functional nanostructured composite materials based on sodium and lithium titanates to produce an anode material with high capacity and working stable potential in the course of cycling with optimal electronic and ionic conductivity were examined. Examples of specific schemes, physical-chemical properties and the mechanism of functional processes by using bioactive and doped components were presented.
\end{abstract}

Keywords: lithium and sodium titanates, functionalization, nanostructuring, ion batteries

DOI: 10.32737/2221-8688-2019-2-216-234

\section{Introduction}

If earlier titanates, in particular titanomagnetites, were mainly of interest for producing titanium dioxide and metallic titanium [1-4], in recent decades titanates have been studied to be used in magneto-optical, ion-conducting and spintronic devices, in lithium-ion batteries for the production of new highly effective catalysts and functional nanoparticles [5-8]. Explorations are carried out to study the effect of bioactive components on functionalization of the surface of nanostructures $[9,10]$.

The most intensively studied are titanates of lithium and sodium, as well as related composite nanostructured functional materials to obtain anode material with high capacity, stability of the operating potential while cycling with optimal electronic and ionic conductivity. A number of books and review articles are devoted to the problem of creating new promising materials based on lithium and sodium titanates [11-16].

The aim of our review is to present in a compact form the highlights of this problem with due regard for new publications on the structure, synthesis and functionalization of lithium and sodium titanates-based nanostructured materials.

\section{Lithium titanates}

The growing interest in lithium titanates is due to the fact that lithium-ion batteries are widely used as compact energy sources in electric vehicles, cell phones, notebooks, etc. Lithium titanates are formed over the quasi- binary $\mathrm{Li}_{2} \mathrm{O}-\mathrm{TiO}_{2}$ cross section of the $\mathrm{Li}-\mathrm{Ti}$ - $\mathrm{O}$ ternary system [17]. Compounds $\mathrm{Li}_{4} \mathrm{TiO}_{4}$, $\mathrm{Li}_{2} \mathrm{TiO}_{3}, \mathrm{Li}_{4} \mathrm{Ti}_{5} \mathrm{O}_{12}$ and $\mathrm{Li}_{2} \mathrm{Ti}_{3} \mathrm{O}_{7}$ are formed in the system $\mathrm{Li}_{2} \mathrm{O}-\mathrm{TiO}_{2}$ (Fig.1). 



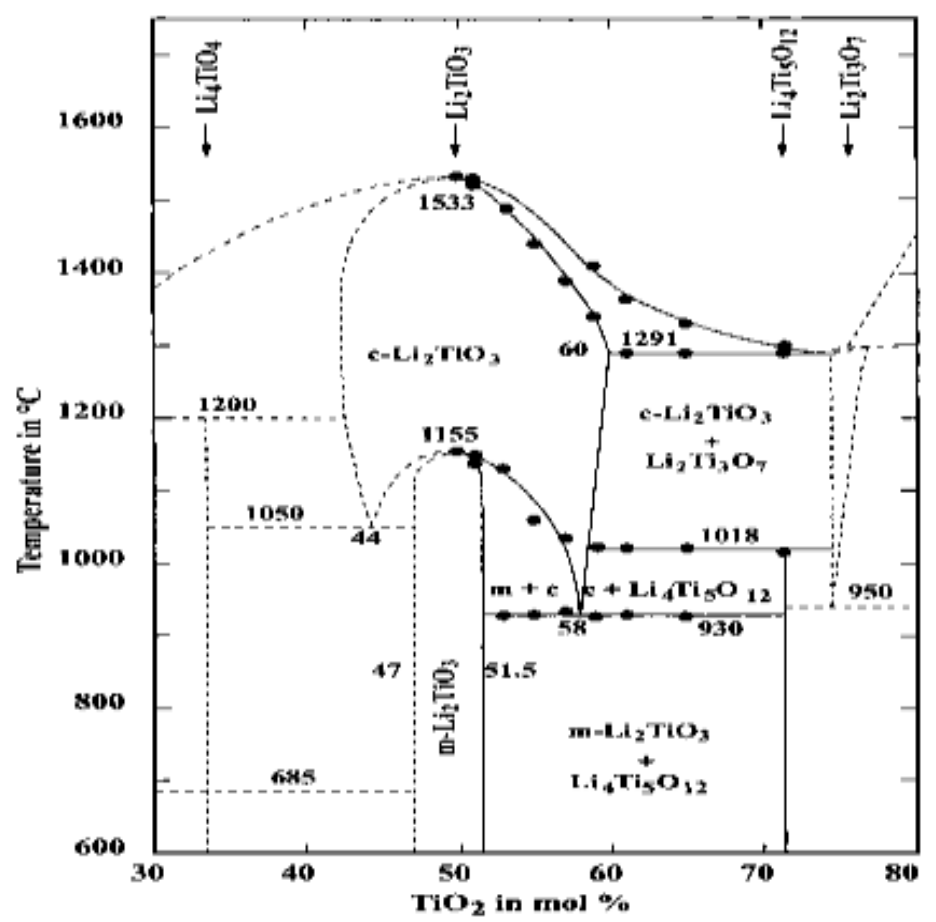

Fig.1. Phase diagram of the $\mathrm{Li}_{2} \mathrm{O}-\mathrm{TiO}_{2}$ system [17].

Note that a high-temperature form of $\mathrm{Li}_{2} \mathrm{TiO}_{3}$ makes up a wide range of solid solutions between $\sim 44$ and $66 \%$ mol $\mathrm{TiO}_{2}$. A lowtemperature form of $\mathrm{Li}_{2} \mathrm{TiO}_{3}$ generates solid solutions between $\sim 47$ and $51 \% \mathrm{TiO}_{2}$. A spinel phase of $\mathrm{Li}_{4} \mathrm{Ti}_{5} \mathrm{O}_{12}$ has an upper stability limit at $1018^{\circ} \mathrm{C}$, above which it decomposes to form $\mathrm{Li}_{2} \mathrm{TiO}_{3}$ and $\mathrm{Li}_{2} \mathrm{Ti}_{3} \mathrm{O}_{7}$. Also, $\mathrm{Li}_{2} \mathrm{Ti}_{3} \mathrm{O}_{7}$ has a lower stability limit at $957 \pm 20^{\circ} \mathrm{C}$, below which it decomposes into $\mathrm{Li}_{4} \mathrm{Ti}_{5} \mathrm{O}_{12}$ and rutile.

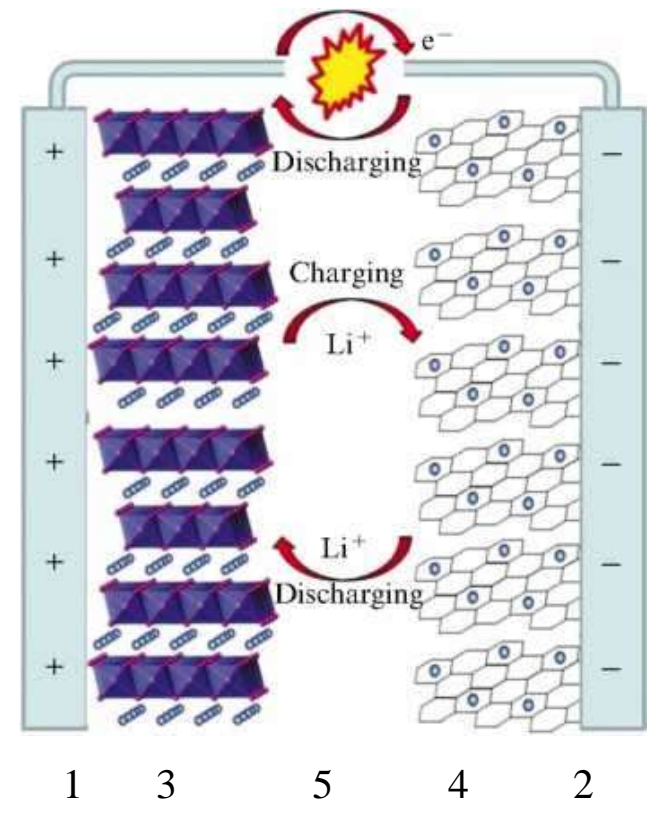

Fig. 2. Schematic diagram LIB [15]: (1) cathode collector, (2) anode collector, (3) cathode material, (4) anode material, (5) separator with electrolyte. 

In the course of the decomposition, a metastable phase of unknown composition forms an intermediate product $\mathrm{Li}_{2} \mathrm{Ti}_{3} \mathrm{O}_{7}$ with a solubility region between $\sim 74$ and $76 \% \mathrm{TiO}_{2}$. Each of the formed phases is of some interest for practice, in particular as an anode material for lithium-ion batteries (LIB). Graphite is usually used as anode material but undergoes changes in the structure in the course of the operation, rapid loss of power in the course of cycling, and a low thermal stability limit is widely used [18]. Currently, one of the most promising anode materials for LIB is lithium titanate $\mathrm{Li}_{4} \mathrm{Ti}_{5} 0_{12}$.

Research into the development of new materials for LIB is aimed at obtaining an anode material with a high working capacity in the course of cycling, with optimal electronic and lithium-ionic conductivity. To a greater extent, these requirements are met by anodic materials based on lithium titanate $\mathrm{Li}_{4} \mathrm{Ti}_{5} \mathrm{O}_{12}$ [19-21]. A schematic diagram of the LIB and reversible electrochemical processes for lithium is shown in Fig.2.3.

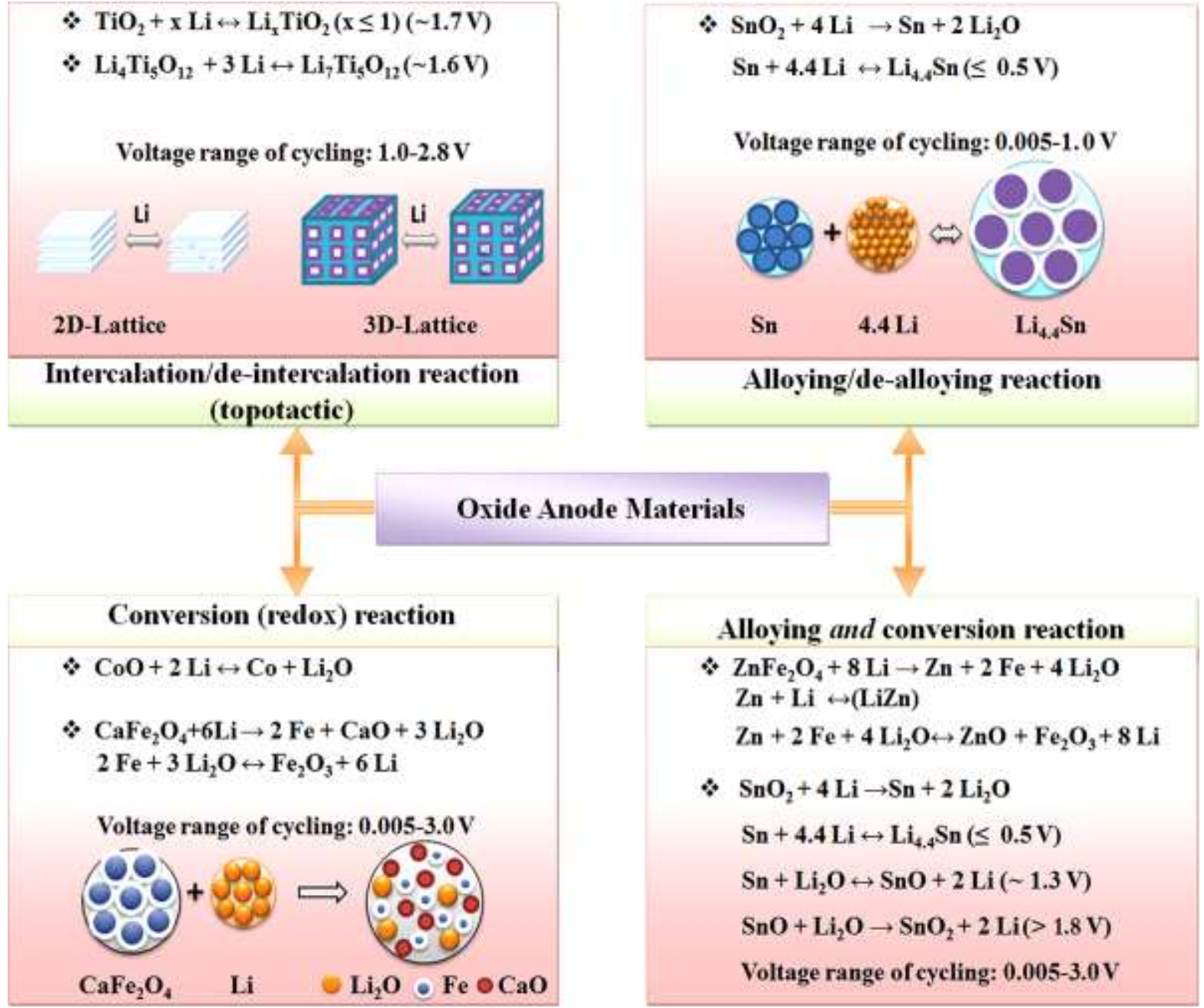

Fig.3. Classification of oxide materials of the anode based on the reversible process of inclusion and extraction of $\mathrm{Li}$ [16]: Intercalation-de-intercalation, alloy formation-exit from the alloy, conversion reaction (redox). The voltage range applies $\mathrm{Li}$.

Electrochemical properties of $\mathrm{Li}_{4} \mathrm{Ti}_{5} \mathrm{O}_{12}$ There are four methods for obtaining phases depend largely on the methods of its synthesis. based on the compound $\mathrm{Li}_{4} \mathrm{Ti}_{5} \mathrm{O}_{12}$. 1) the 
Pechini sol-gel method [22,23], 2) the citrate method using $\mathrm{C}_{6} \mathrm{H}_{8} \mathrm{O}_{7}$ citric acid and 3) the EDTA-citrate method using the ethylenediaminetetraacetic $\mathrm{C}_{10} \mathrm{H}_{16} \mathrm{~N}_{2} \mathrm{O}_{8}$ and citric acids [24]. The last three methods were used to obtain $\mathrm{Li}_{4} \mathrm{Ti}_{5} \mathrm{O}_{12}$ in [18]. According to the Pechini method, titanium tetrabutylate was successively added to the mixture of ethylene glycol + nitric acid with constant stirring $\left(\mathrm{C}_{4} \mathrm{H}_{9} \mathrm{O}\right)_{4} \mathrm{Ti}, \mathrm{C}_{6} \mathrm{H}_{8} \mathrm{O}_{7}$ and $\mathrm{Li}_{2} \mathrm{CO}_{3}$. The molar ratio of titanium ions in respect of citric acid was 1:4. The resulting mixture was kept at 368 and $423 \mathrm{~K}$ for 24 hours. Under these conditions, molecules of ethylene glycol and citric acid enter into a polycondensation reaction which leads to the formation of a polymer gel and a subsequent pyrolysis at 623 $\mathrm{K}$ for $5 \mathrm{~h}$. When using the EDTA-citrate method $\left(\mathrm{C}_{4} \mathrm{H}_{9} \mathrm{O}\right)$, 4Ti and $\mathrm{Li}_{2} \mathrm{CO}_{3}$ were dissolved in a mixture of ethanol + nitric acid (volume ratio of 5: 1). Note that EDTA and $\mathrm{C}_{6} \mathrm{H}_{8} \mathrm{O}_{7}$ were added to the resulting solution. The molar ratio of metal ions to EDTA and $\mathrm{C}_{6} \mathrm{H}_{8} \mathrm{O}_{7}$ was 1: 1: 2. Next, the mixture was heated at $368 \mathrm{~K}$ until a gelatin-like mass formed which was then kept at $523 \mathrm{~K}$ for 5 hours. However, as for single-phase $\mathrm{Li}_{4} \mathrm{Ti}_{5} \mathrm{O}_{12}$ in the presence of a high theoretical capacity of $175 \mathrm{mAh} / \mathrm{g}$ and an operating potential of $1.5 \mathrm{~V}\left(\mathrm{Li} / \mathrm{Li}^{+}\right)$, values of electronic and lithium-ionic conductivity proved to be low $[19,20]$. To improve the conductivity, doping was carried out with various cations $\left(\mathrm{V}^{5+}\right.$, $\mathrm{Nb}^{5+}, \mathrm{Zr}^{4+}, \mathrm{Al}^{3+}, \mathrm{Cr}^{3+}, \mathrm{Mg}^{2+}, \mathrm{Sn}^{2+}$, etc.) in the positions of titanium and lithium $[25,26]$. An increase in the conductivity (first of all electronic) can also be achieved due to the formation of composites with carbon or metals [27].

In [28] $\mathrm{Li}_{4} \mathrm{Ti}_{5} \mathrm{O}_{12}$ was considered as a promising electrode material for lithium secondary batteries. The spray drying process was used to obtain porous and spherical $\mathrm{Li}_{4} \mathrm{Ti}_{5} \mathrm{O}_{12}$ powders from $\mathrm{Li}_{2} \mathrm{CO}_{3}$ and rutile $\mathrm{TiO}_{2}$ as precursors for pore formation. Experimental results showed that porous and spherical morphologies are preserved in the course of the sintering and subsequent heat treatment. At the same time, excessive heat treatment may result in losing the lithium content and, consequently, reducing the charge and discharge power. Porous carbon substances have a low specific capacity; at the same time as an intercalation type the materials with asymmetric capacity have a limited ion velocity. In [28], it found that intercalationtype nanoparticles of lithium titanate $\left(\mathrm{Li}_{4} \mathrm{Ti}_{5} \mathrm{O}_{12}\right)$ in carbon nanopores are nanocomposites with both high ionic density and high ion transfer rate through open and interconnected pore channels.

In [6] carbon encapsulated $\mathrm{Li}_{4} \mathrm{Ti}_{5} \mathrm{O}_{12}$ $\left(\mathrm{C} / \mathrm{Li}_{4} \mathrm{Ti}_{5} \mathrm{O}_{12}\right)$ anode material for lithium ion battery was prepared by using the pre-coat method of two steps, and the $\mathrm{TiO}_{2}$ was precoated before the reaction with $\mathrm{Li}_{2} \mathrm{CO}_{3}$. The structure and morphology of the resultant $\mathrm{C} / \mathrm{Li}_{4} \mathrm{Ti}_{5} \mathrm{O}_{12}$ materials were characterized by X-ray diffraction (XRD) and scanning microscopy (SEM). Electrochemical tests showed that at $0.1 \mathrm{C}$, the initial discharge capacity was $169.9 \mathrm{mAh} \mathrm{g}^{-1}$, and the discharge capacity was $80 \mathrm{mAh} \mathrm{g}^{-1}$ at $5 \mathrm{C}$. After 100 cycles at $2 \mathrm{C}$, the discharge specific capacity was $108.5 \mathrm{mAh} \mathrm{g}^{-1}$. As compared to one step coating method, results showed that the $\mathrm{C} / \mathrm{Li}_{4} \mathrm{Ti}_{5} \mathrm{O}_{12}$ prepared by pre-coat method can reduce a particle's size and effectively improve the electrochemical performance. In [7] the spinel $\mathrm{Li}_{4} \mathrm{Ti}_{5} \mathrm{O}_{12}$ (LTO) was doped by $\mathrm{Ca}^{2+}$ via a solid-state reaction route generating highly crystalline $\mathrm{Li}_{3.9} \mathrm{Ca}_{0.1} \mathrm{Ti}_{5} \mathrm{O}_{12}$ powders with a view of improving their electrochemical performance as an anode. The structure changes, morphologies, and electrochemical properties of the resultant powders were characterized by X-ray diffraction (XRD), scanning electron microscopy (SEM), and cyclic voltammetry (CV), respectively. Crystal structure and composition were analyzed, and results obtained with various tests of LTO. Electrochemical measurements revealed that $\mathrm{Li}_{3.9} \mathrm{Ca}_{0.1} \mathrm{Ti}_{5} \mathrm{O}_{12}$ anodes exhibit better rate capability, better cycling stability, and higher specific capacity than pure LTO anodes. In [8] Composites of $\mathrm{Li}_{4} \mathrm{Ti}_{5} \mathrm{O}_{12}$ with $\mathrm{Ag}-\mathrm{Cu}$ particles were successfully synthesized by solid-state reaction followed by thermal decomposition of metal substrates. The presence of metallic particles was confirmed by X-ray diffraction, 
scanning transmission electron microscopy and X-ray photoelectron spectroscopy. Galvanostatic charge-discharge tests showed improved specific capacity and capacity retention of $\mathrm{Li}_{4} \mathrm{Ti}_{5} \mathrm{O}_{12} / \mathrm{Ag}-$ $\mathrm{Cu}$ composites at a $10 \mathrm{C}$ current rate, while cyclic voltammetry and electrochemical impedance spectroscopy revealed changes in $\mathrm{Li}^{+}$ion chemical diffusion coefficient values and chargetransfer resistance with increasing amount of $\mathrm{Ag}-\mathrm{Cu}$ in prepared powders. The synthesis and structural, morphological and electrochemical evaluation of $\mathrm{Li}_{4} \mathrm{Ti}_{5} \mathrm{O}_{12} / \mathrm{Ag}-\mathrm{Cu}$ powders carried out in this work were also presented here for the first time.

\section{Sodium titanates}

Sodium titanates are formed over the quasi-binary section of $\mathrm{Na}_{2} \mathrm{O}-\mathrm{TiO}_{2}$ of the NaTi-O ternary system (Fig.4): $\mathrm{Na}_{4} \mathrm{TiO}_{4}$, $\mathrm{Na}_{2} \mathrm{TiO}_{3}, \mathrm{Na}_{4} \mathrm{Ti}_{6} \mathrm{O}_{14}, \mathrm{Na}_{2} \mathrm{Ti}_{3} \mathrm{O}_{7}$ and $\mathrm{Na}_{2} \mathrm{Ti}_{6} \mathrm{O}_{13}$. Of the sodium titanates, sodium trititanate $\mathrm{Na}_{2} \mathrm{Ti}_{3} \mathrm{O}_{7}$ was explored most intensively. Sodium trititanate was mainly obtained in the form of nanotubes (T3Ns) and nanofibers (T3NFs). It should be noted that T3NTs and
T3NFs have high specific surface area, ionexchange capacity and proton conductivity. Therefore, they can be used as a catalyst [29], catalyst carriers [30], energy storage electrodes [31], proton exchange membrane of fuel cells [32] to remove pollutants [33]. Because of their biocompatibility and hydrophobicity, T3NTs are used as nanobiocatalysts (immobilization of enzumes [34].

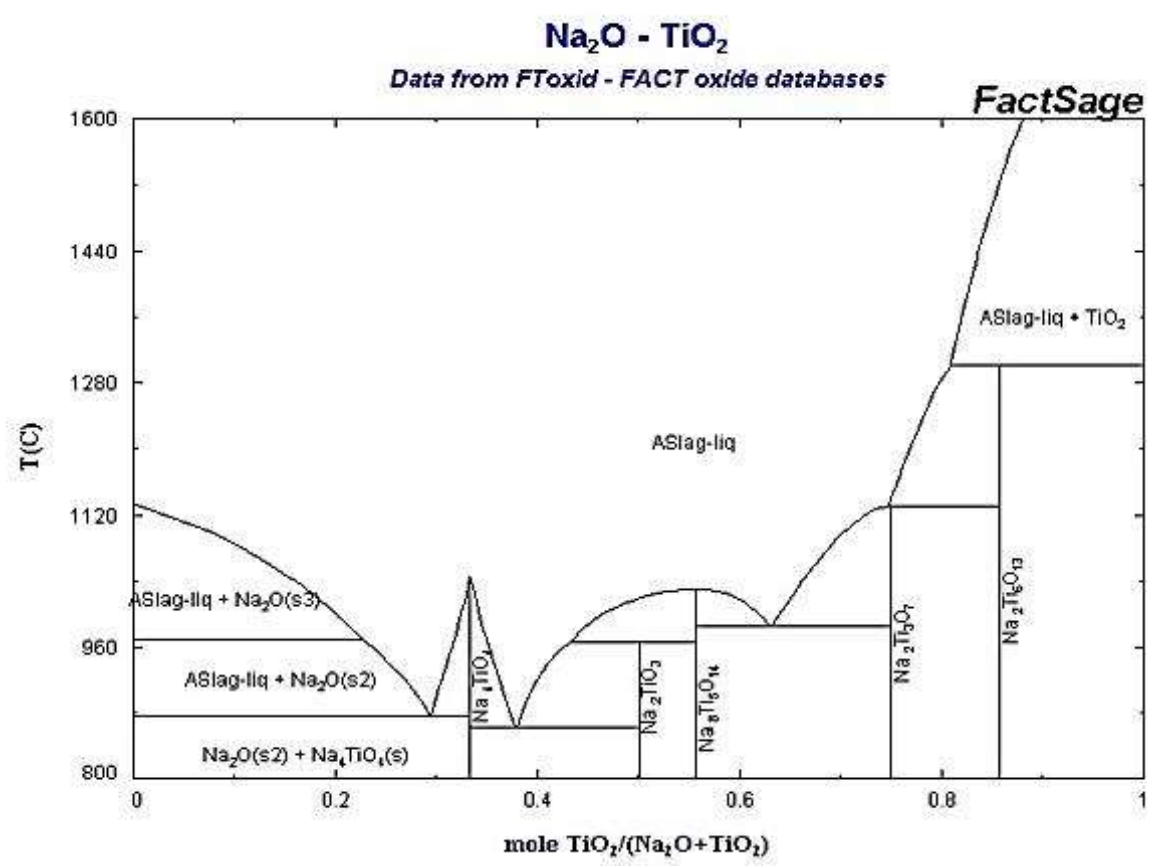

Fig.4. Phase diagram of the $\mathrm{Na}_{2} \mathrm{O}-\mathrm{TiO}_{2}$ system.

\section{Methods of synthesizing $\mathrm{Na}_{2} \mathrm{Ti}_{3} \mathrm{O}_{7}$ and obtaining nanotubes (T3NTs) and nanofibers (T3N)}

The mechanism of formation of T3NTs nanotubes has been the subject of the research [35] whose authors suggested that lamellar sheets are formed as a result of alkaline hydrothermal processing. The removal of sodium ions by acid washing leads to the scrolling of sheets in the form of nanotubes (acid washing mechanism). The authors of [36, 37] suggested that nanotubes are formed as a result of four staged hydrothermal processing 
(the peeling-scrolling mechanism). In [38-42], the microwave hydrothermal treatment method was used to obtain different sizes of $\mathrm{TiO}_{2}$ nanotubes. In particular, nanotubes of sodium titanate NaTiNTs were synthesized in [43] by microwave hydrothermal treatment of $\mathrm{TiO}_{2}$. The synthesis of nanotubes was carried out in the following sequence: $0.7 \mathrm{~g}$ of $\mathrm{TiO}_{2}$ was dispersed in $7 \mathrm{ml}$ of $10 \mathrm{M} \mathrm{NaOH}$ solution, stirred at a room temperature for $1 \mathrm{~h}$, then for about $15 \mathrm{~min}$, followed by sonication, and then stirred again for $10 \mathrm{~min}$. Next, $6 \mathrm{ml}$ of the reaction mixture was poured into a silicon carbide flask and placed in a microwave reactor (Anton Paar, Monowave 300). The reaction was carried out at a constant temperature of $135^{\circ} \mathrm{C}$ for $15 \mathrm{~min}, 1,4,8$, and $16 \mathrm{~h}$. A more detailed description of the experiment is given in [43]. Nanotubes were observed as early as 15 min after microwave irradiation. Analyses of products irradiated for 8 and 16 hours confirm the complete conversion of $\mathrm{TiO}_{2}$ powder into NaTiNTs (Fig. 5).

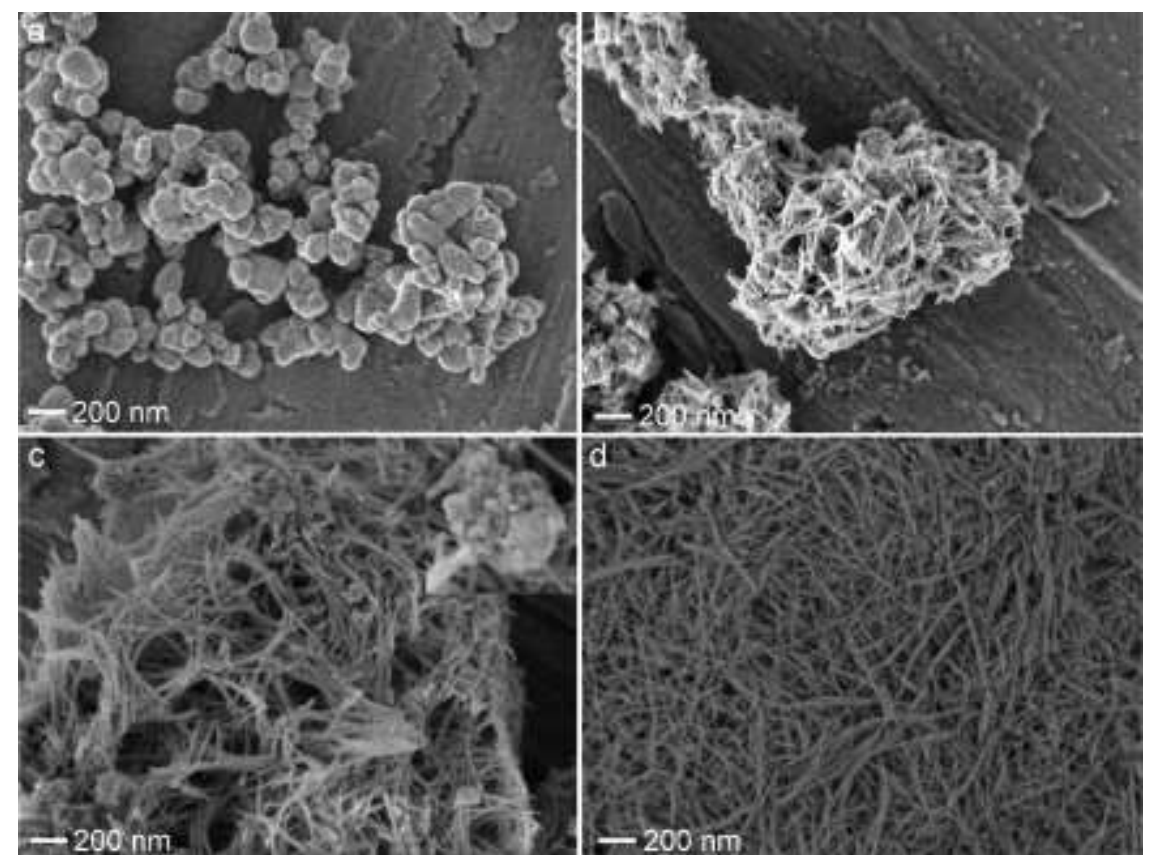

Fig. 5. SEM images, starting with $\mathrm{TiO}_{2}$ (a), before the products separated after $15 \mathrm{~min}$ (b), 1 hour (s) and 8 hours $(\mathrm{g})$ were processed in a microwave reactor at $1350 \mathrm{C}$. All images were taken at the same magnification [43].

\section{Hydrothermal synthesis of nanoparticles of sodium titanates}

In recent years, a large number of experimental approaches have been successfully used to synthesize nanowires based on titanium dioxide. These include the sol-gel method in combination with electrophoretic deposition [44], spin method [45], sol-gel standard method [45,46], deposition of organometallic compounds from the vapor $[47,48]$, anodic oxidative hydrolysis [49], sono-chemical synthesis [50], reverse micro-emulsion [51], pyrolysis-assisted melting of salts [52], hydrothermal synthesis
[53-55] of titanium dioxide-based rod-shaped nanostructures. The advantage of this method is that nanotubes or nanowires can be obtained in relatively large quantities. Hydrothermal treatment of $\mathrm{TiO}_{2}$ precursors in a strongly alkaline medium is an efficient way to prepare titanium dioxide-based nanotubes and nanofibers. For example, $\mathrm{K}_{2} \mathrm{Ti}_{6} \mathrm{O}_{13}$ nanofibers were successfully obtained hydrothermally using $\mathrm{KOH}$ in [54]. In [55], it showed that nanowires and nanotubes can also be obtained using $\mathrm{NaOH}$. However, information about the 
structure of synthesized nanoparticles remained unclear, despite intensive research. In [56] it was reported that the products of hydrothermal treatment of the anatase modification of $\mathrm{TiO}_{2}$ with $\mathrm{NaOH}$ are nanotubes of polytitanates of the $\mathrm{Na}_{\mathrm{x}} \mathrm{H}_{2-\mathrm{x}} \mathrm{Ti}_{3} \mathrm{O}_{7}$ composition. Later [57] reported that the synthesized nanotubes or nanotubes have even more complex composition, to be exact, $\mathrm{Na}_{x} \mathrm{H}_{2-\mathrm{x}} \mathrm{Ti}_{\mathrm{n}} \mathrm{O}_{2 \mathrm{n}+1} \cdot \mathrm{yH}_{2} \mathrm{O}$. By treating these nanoparticles with a $\mathrm{HCl}$ solution, nanotubes and nano-sticks with $\mathrm{H}_{2} \mathrm{Ti}_{3} \mathrm{O}_{7}$ composition were obtained.

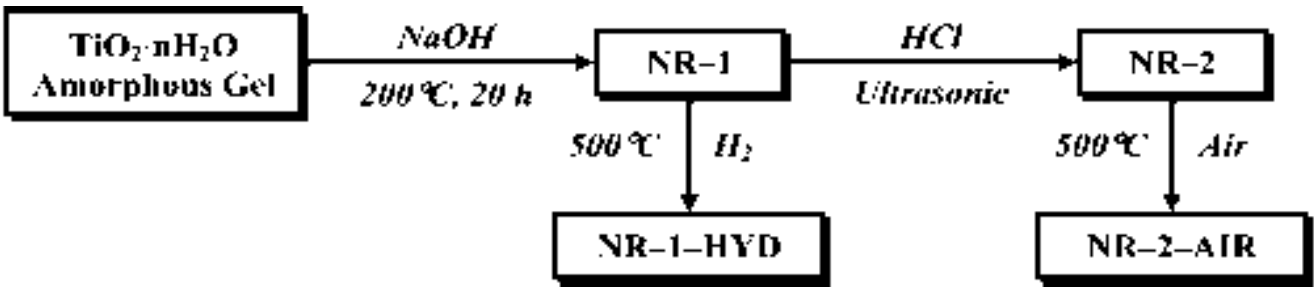

Scheme 1. Hydrothermal treatment of amorphous $\mathrm{TiO}_{2} \cdot \mathrm{nH}_{2} \mathrm{O}$ using 10 molar solution of $\mathrm{NaOH}$ and 0.1 molar solution of hydrochloric acid to produce nano-sticks: NR-1 denotes $\mathrm{Na}_{2} \mathrm{Ti}_{\mathrm{n}} \mathrm{O}_{2 \mathrm{n}+1}(\mathrm{n}=3,4,9), \mathrm{NR}-2: \mathrm{H}_{2} \mathrm{Ti}_{3} \mathrm{O}_{7}, \mathrm{NR}-1-\mathrm{HYD}$ : in a stream of hydrogen, NR-2-AIR: in the air flow [53].

In [53], hydrothermal conditions of thermal and chemical treatment of amorphous phases for the preparation of titanates with the general formula $\mathrm{Na}_{2} \mathrm{Ti}_{n} \mathrm{O}_{2 n+1}$ were studied more thoroughly. The process of formation of titanium-like nanopacks from amorphous $\mathrm{TiO}_{2} \cdot \mathrm{nH}_{2} \mathrm{O}$ gels in the process of hydrothermal synthesis was explored. Note that nanoparticles of $\mathrm{Na}_{2} \mathrm{Ti}_{3} \mathrm{O}_{7}$ sodium trititanate rod-shaped morphology were obtained using simple hydrothermal treatment in the presence of a concentrated aqueous solution of $\mathrm{NaOH}$. The ion-exchange reaction of the synthesized $\mathrm{Na}_{2} \mathrm{Ti}_{3} \mathrm{O}_{7}$ nano-sticks with $\mathrm{HCl}$ in the course of ultrasonic processing led to the complete replacement of sodium ions and the formation of $\mathrm{H}_{2} \mathrm{Ti}_{3} \mathrm{O}_{7}$ nanopalicle (Scheme 1).

Low-temperature annealing of $\mathrm{Na}_{2} \mathrm{Ti}_{3} \mathrm{O}_{7}$ and $\mathrm{H}_{2} \mathrm{Ti}_{3} \mathrm{O}_{7}$ nano-sticks leads to the loss of a layered crystal structure and the formation of sodium hexane-titanate nano-sticks $\left(\mathrm{Na}_{2} \mathrm{Ti}_{6} \mathrm{O}_{13}\right)$ and the metastable $\mathrm{TiO}_{2}-\mathrm{B}$ phase, (Fig. 6). The analyzed methods for the synthesis of nanostructures of active metal titanates are successfully applied in [58-64]. In [58], sodium titanate nanopowder (nominal formula $\mathrm{Na}_{1.5} \mathrm{H}_{0.5} \mathrm{Ti}_{3} \mathrm{O}_{7}$ ) was directly synthesized using a continuous hydrothermal flow synthesis process with the help of a relatively low base concentration $(4 \mathrm{M} \mathrm{NaOH})$ in the process. The as-made titanate nanomaterials were characterized using powder X-ray diffraction, X-ray photoelectron spectroscopy, energy-dispersive X-ray spectroscopy, Raman spectroscopy, BrunauerEmmett-Teller analysis and transmission electron microscopy to evaluate results as potential electrode materials for $\mathrm{Li}$-ion and Na-ion batteries. Cyclic voltammetry studies on half-cells revealed that the sodium titanate nanomaterial stored the charge primarily through a combination of pseudo-capacitive and diffusion-limited processes in both systems. Electrochemical cycling tests at a high specific current of $1000 \mathrm{~mA} \mathrm{~g}-1$ revealed that the Li-ion and Na-ion cells retained their relatively high specific capacities after 400 cycles of 131 and $87 \mathrm{mAh} \mathrm{g-1,} \mathrm{respectively.}$ This study demonstrates the potential of CHFS-made sodium titanate nanopower as an anode material for both $\mathrm{Li}$ - and Na-ion cell chemistries. 


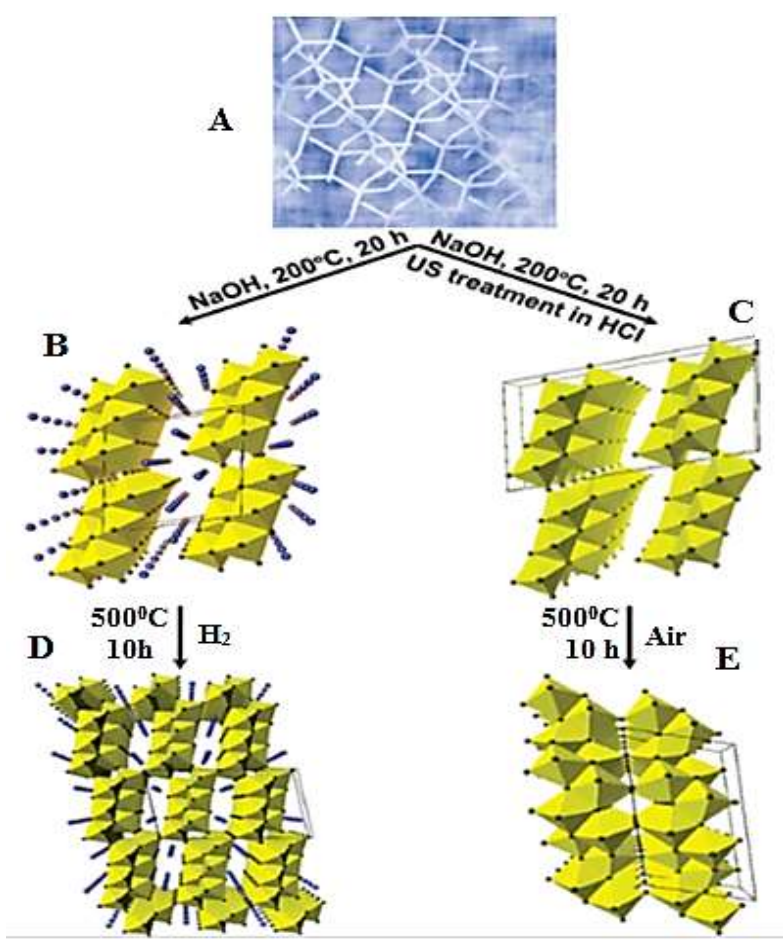

Fig.6. The scheme of frame transformations in the course of hydrothermal and chemical treatment of amorphous $\mathrm{TiO}_{2} \cdot \mathrm{nH}_{2} \mathrm{O}$ [19]: (A) amorphous gel $\mathrm{TiO}_{2} \cdot \mathrm{nH}_{2} \mathrm{O}$; (B) $\mathrm{Na}_{2} \mathrm{Ti}_{3} \mathrm{O}_{7}$; (C) $\mathrm{H}_{2} \mathrm{Ti}_{3} \mathrm{O}_{7}$; (D) $\mathrm{Na}_{2} \mathrm{Ti}_{6} \mathrm{O}_{13}$; (E) $\mathrm{TiO}_{2}-\mathrm{B}$.

\section{Using nanotubes and nanofibers $\mathrm{Na}_{2} \mathrm{Ti}_{3} \mathrm{O}_{7}$ to capture radioactive ions}

Titanates and silikotitanate as zeolites, are cost-effective materials for cleaning contaminated water from radioactive ions [65]. Promising for the adsorption and safe disposal of ${ }^{137} \mathrm{Cs}^{+}$radioactive ions from an aqueous solution are nanotubes and $\mathrm{Na}_{2} \mathrm{Ti}_{3} \mathrm{O}_{7}$ nanofibres. In [66], nanofibres and nanotubes of $\mathrm{Na}_{2} \mathrm{Ti}_{3} \mathrm{O}_{7}$ were synthesized under hydrothermal conditions. The materials obtained have a layered structure where the $\mathrm{TiO}_{6}$ octahedra are basic structural units [67]. These layers carry negative charges about two oxygen atoms thick. $\mathrm{Na}^{+}$ions are located between the layers and can be exchanged with other cations. In [66], nanofibres (T3NF) and nanotubes (T3NT) were used to remove ${ }^{137} \mathrm{Cs}^{+}$ radioactive ions from an aqueous solution by exchanging cations. This process with a structural change (Fig. 7) is described by the reaction as follows:

$$
2 \mathrm{Na}_{2} \mathrm{Ti}_{3} \mathrm{O}_{7}+(1-0.5 x) \mathrm{Cs}^{+}+(1-0.5 x) \mathrm{H}^{+}+\mathrm{H}_{2} \mathrm{O}
$$$$
\rightarrow \mathrm{Na}_{x} \mathrm{Cs}_{1-0.5 x} \mathrm{H}_{1-0.5 \mathrm{x}} \mathrm{Ti}_{6} \mathrm{O}_{13}+(4-x) \mathrm{Na}^{+}+2 \mathrm{OH}^{-}
$$

The $\mathrm{Cs}^{+}$ions are located in the T6NF fiber tunnels. A maximum width of the tunnel along [010] direction is about $0.327 \mathrm{~nm}$. Since the diameter of the $\mathrm{Cs}^{+}$ion is $0.330 \mathrm{~nm}$, it will be difficult for the ${ }^{137} \mathrm{Cs}^{+}$ions to diffuse into the tunnels and the ions will be trapped in the fibers. T6NF is more stable than T3NF at higher temperatures. This property is an advantage for the safe disposal of immobilized radioactive ions. The structure evolution from the initial titanate $\mathrm{NF}$ to $\mathrm{Ag}_{2} \mathrm{O}-\mathrm{T} 3 \mathrm{NF}$ was also studied in [66] (Fig. 8). The titanate NF fibers consist of octahedral $\mathrm{TiO}_{6}$ plates and an open plane (100) (Fig. 8a). When $\mathrm{Ag}^{+}$ions diffuse on the surface of titanate $\mathrm{NF}$ in a neutral or alkaline medium, $(\mathrm{Ag})(\mathrm{OH})_{\mathrm{n}}\left(\mathrm{H}_{2} \mathrm{O}\right)_{\mathrm{m}}$ silver intermediates are formed on the surface. These intermediate products are dehydrated on the Ti-OH surface and are bound to the surface by exchanging the surface oxygen atoms of the octahedral $\mathrm{TiO}_{6}$ plates in the (100) planes (Fig. 8, b) which leads to the deformation of the (100) plane surface and, therefore, the plane proper. 


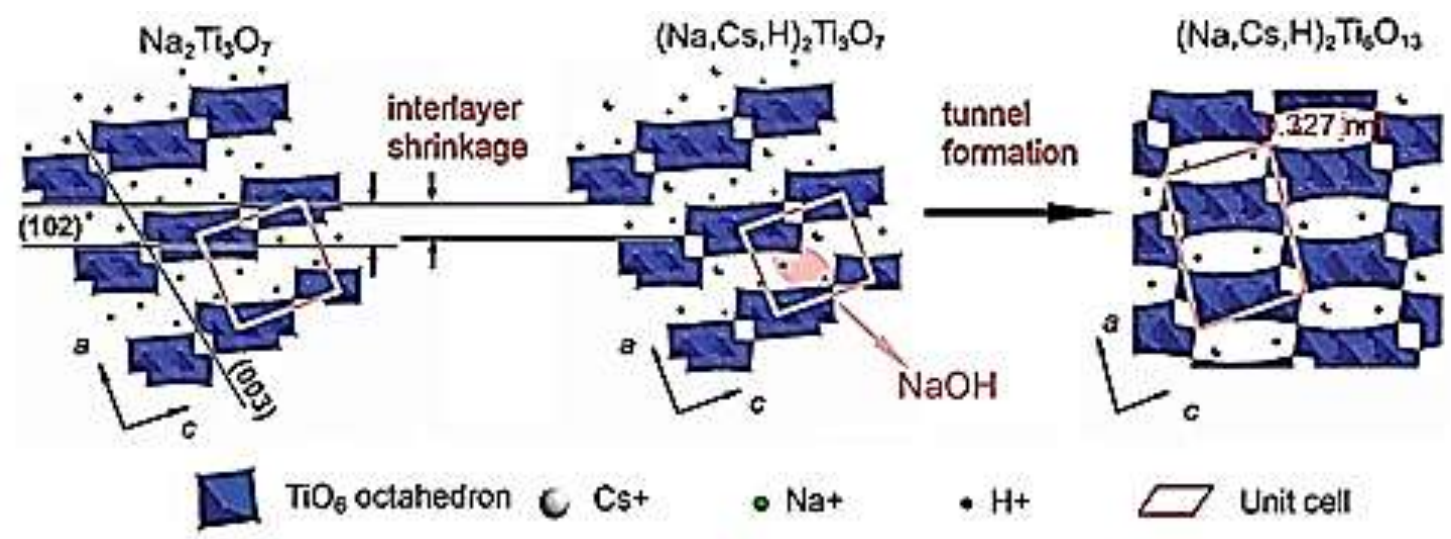

Fig.7. Evolution of the structure of T3NF-layered nanofibers into a microporous T6NF tunnel structure [66].

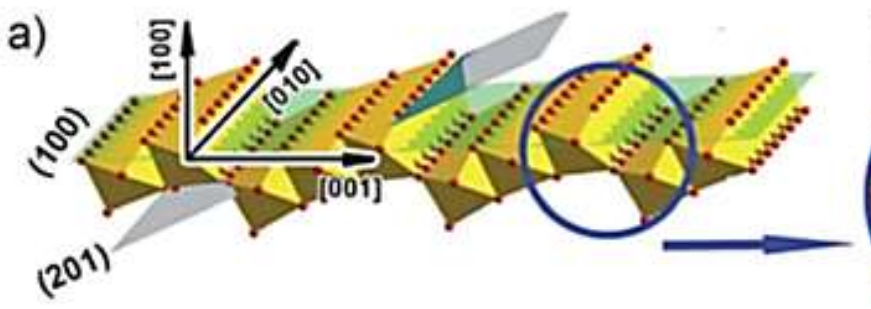

d)

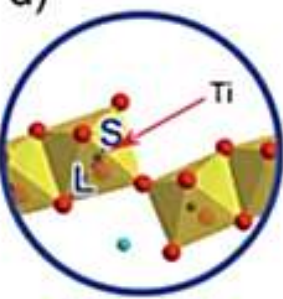

b)

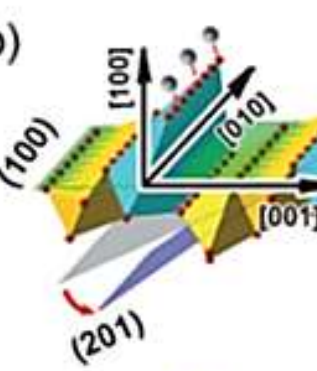

e)
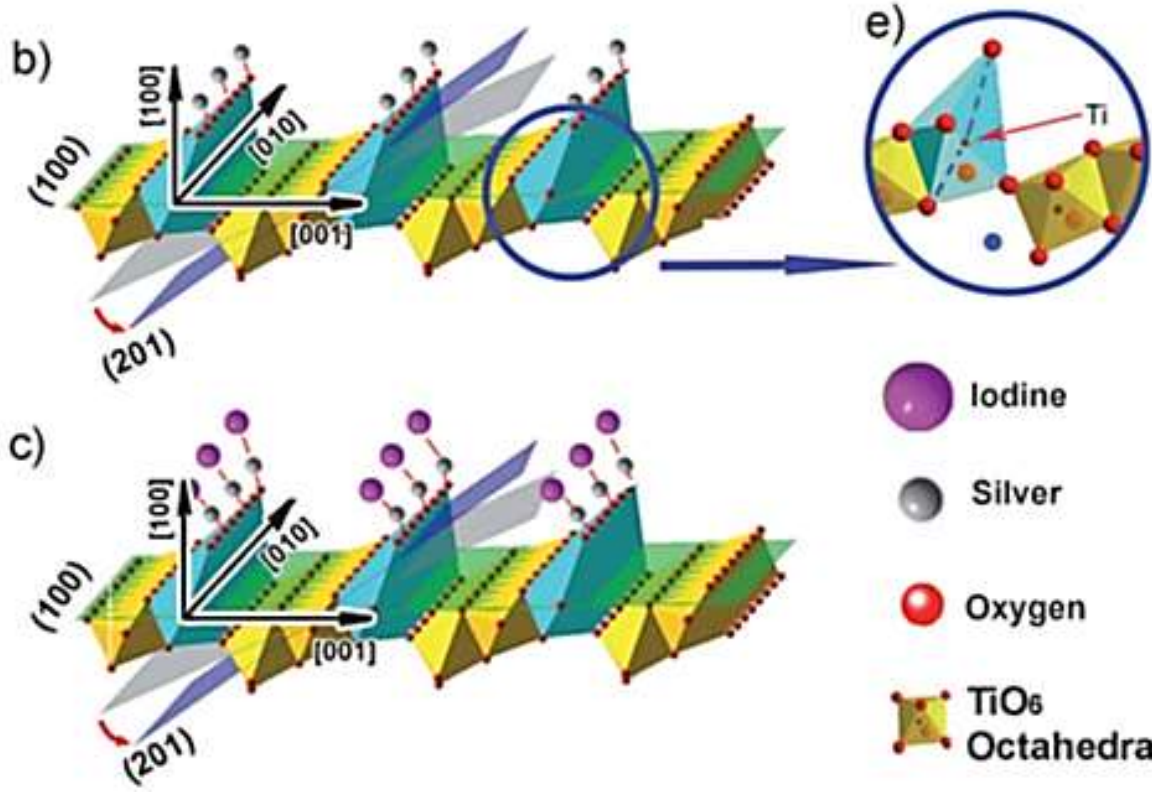

lodine

Q) Silver
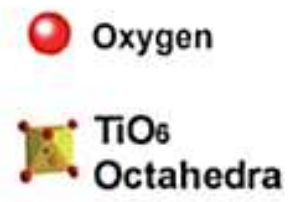

Fig.8. Formation of $\mathrm{Ag}_{2} \mathrm{O}$ nanocrystals profile on (100) plane of the titanate nanofibres and the deposition of iodide ions: a) surface of the titanate nanofibre. b, c) deformation on (100) and (201) planes after deposition of $\mathrm{Ag}_{2} \mathrm{O}$ nanocrystals and adsorption of iodide ions. d) $\mathrm{TiO}_{6}$ octahedra of titanate substrates, e) distorted $\mathrm{TiO}_{6}$ octahedra: in the course of the deformation process of $\mathrm{TiO}_{6}$, a short Ti-O bond disappears and a long $\mathrm{Ti}-\mathrm{O}$ bond forms [66]. 

In addition, $\mathrm{Ag}^{+}$ions are exchanged with $\mathrm{Na}+$ ions inside the interlayer space which leads to a deterioration in crystallinity and a decrease in the diffraction intensity. The diffraction intensity (201) of the planes (blue plane in Fig. 8 b) may significantly drop. In (201), the planes are partially occupied by oxygen atoms and $\mathrm{Na}^{+}$ions inside the interlayer space in the initial fibers. These $\mathrm{Na}^{+}$ ions are replaced by $\mathrm{Ag}^{+}$ions that strongly interact with oxygen atoms; this substitution resulted in a small displacement of oxygen atoms from their original positions to affect the diffraction intensity. The structure evolution was also confirmed by measuring short Ti-O bonds (bonds between terminal oxygen atoms and a central titanium atom in the distorted $\mathrm{TiO}_{6}$ octahedra labeled with $\mathrm{S}$ in Fig. 10d) and long $\mathrm{Ti}-\mathrm{O}$ bonds (bonds between bridging oxygen atoms and the titanium atom in the same octahedra, labeled $\mathrm{L}$ in Fig.8d).

\section{Titanates functionalization by bioactive components and doping}

The functionalization of the surface of one-dimensional nanostructures with bioactive components allows forming textures, morphology and phase composition of products in the course of hydrothermal treatment of doped titanium dioxide powders and titanates $[9,10,68]$. In particular, in [10] was studied the influence of bioactive natural polymer chitosan as the organic reactant in the formation of texture morphology and phase composition of products in the course of hydrothermal treatment $\mathrm{CoTiO}_{3}$ and $\mathrm{TiO}_{2}$ powders obtained from hydrosols pre-formed electrochemical sol-gel method. The behavior of sodium titanates when exposed to a simulated body fluid SBF was studied in $[69,70]$. Suffice it to recall that the simulated body fluid (SBF) is a solution with a concentration of the ions close to the human blood plasma. In particular, it was found in [70] that an increased content of sodium entails a higher biological activity, since more sodium ions are available for exchange with $\mathrm{H}_{3} \mathrm{O}^{+}$ions in $\mathrm{SBF}$, which leads to the formation of $\mathrm{Ti}-\mathrm{OH}$ groups and then intermediate calcium titanate. A local increase in $\mathrm{pH}$ causes the formation of a biomimetic calcium phosphate layer on the surface. Sintering of the samples leads to the formation of a larger number of three- and hexatitanate crystal structures and a decrease in the sodium content. The amount of $\mathrm{Na}^{+}$ions that can be released from the surface of sodium titanate is reduced due to decreasing surface area and low sodium content. When the sintered samples are treated with an aqueous solution of $\mathrm{NaOH}$, some of the $\mathrm{Ti}-\mathrm{O}-\mathrm{Ti}$ bonds are broken and $\mathrm{Ti}-\mathrm{O}-\mathrm{Na}$ and $\mathrm{Ti}-\mathrm{OH}$ bonds are formed. This process is enhanced in the SBF medium by exposure to hydroxonium ions. In work [71], nanoscale porous lithium titanate (LTO) as an anode material was synthesized using the method of spray drying after grinding in a ball mill. LTO nanoparticle size was optimized at a rate of 200 for stable performance. It was found that the electrochemical characteristics of the synthesized LTO nanoparticles are stable at high operating temperature $\left(50^{\circ} \mathrm{C}\right)$ and at high current speeds.

In the work [72], a series of samples of $\mathrm{Li}_{2} \mathrm{BaTi}_{6} \mathrm{O}_{14}$ was synthesized by the traditional solid-phase method - calcination at various temperatures from 800 to $1000^{\circ} \mathrm{C}$. Structural analysis and electrochemical evaluation showed that the optimal firing temperature for $\mathrm{Li}_{2} \mathrm{BaTi}_{6} \mathrm{O}_{14}$ is $950^{\circ} \mathrm{C}$. $\mathrm{Li}_{2} \mathrm{BaTi}_{6} \mathrm{O}_{14}$, calcined at $950 \circ \mathrm{C}$, has high phase purity with excellent reversible capacity of $145.7 \mathrm{mAh} / \mathrm{g}$ for the first cycle at a current density of $50 \mathrm{~mA}$ /g. After 50 cycles, reversible capacity can be maintained at $137.7 \mathrm{mAh} / \mathrm{g}$, while maintaining a potential of $94.51 \%$.

The work [73] deals with obtaining new electrorheological (ER) materials using microwave synthesis with the provision of a suitable shell with due regard for the electrorheological effect. In the work [74], ultrathin layered sodium titanate nanofilms were synthesized using a continuous process of hydrothermal flow and explored as anode material for lithium-ion batteries. [75] 
examined the low-temperature execution of the start /stop command for LMO / LTO (lithium manganese oxide/lithium titanate) lithium-ion batteries with three different electrolytes. [76] reported on the successful use of perovskite structured lithiumlanthanum-titanate (LLTO) material in LIB.

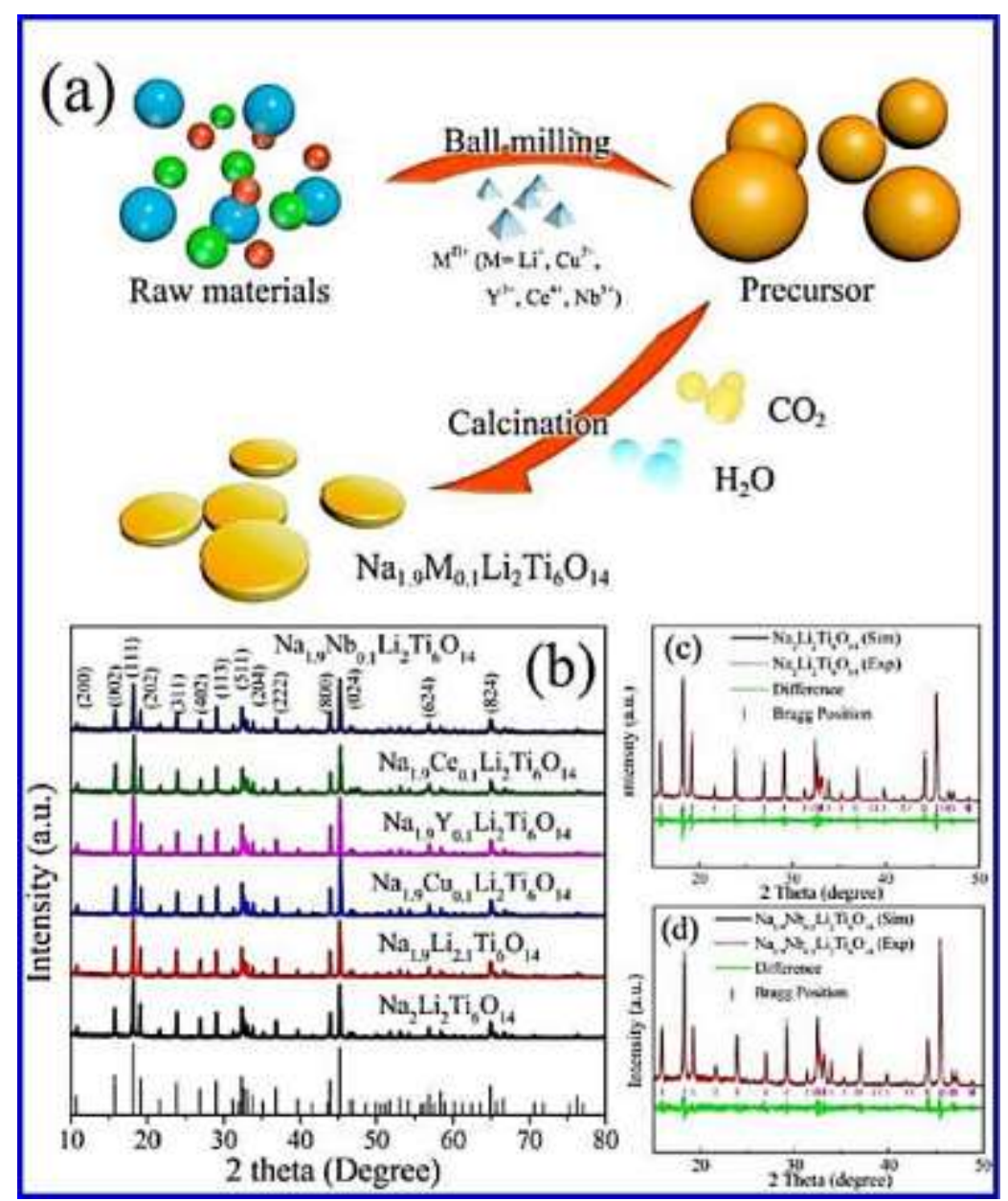

Fig.9. (a) Schematic representation of the synthesis process, (b) XRD of $\mathrm{Na}_{2} \mathrm{Li}_{2} \mathrm{Ti}_{6} \mathrm{O}_{14}$ и $\mathrm{Na}_{1.9} \mathrm{M}_{0.1} \mathrm{Li}_{2} \mathrm{Ti}_{6} \mathrm{O}_{14}\left(\mathrm{M}=\mathrm{Li}^{+}, \mathrm{Cu}^{2+}, \mathrm{Y}^{3+}, \mathrm{Ce}^{4+}, \mathrm{Nb}^{5+}\right)$, (c) Rietveld processing profiles for $\mathrm{Na}_{2} \mathrm{Li}_{2} \mathrm{Ti}_{6} \mathrm{O}_{14} ;$ (d) Rietveld profiles processing $\mathrm{Nb}$-doped $\mathrm{Na}_{2} \mathrm{Li}_{2} \mathrm{Ti}_{6} \mathrm{O}_{\mathrm{M}}$ [77]

By doping with $\mathrm{Li}(+), \mathrm{Cu}(2+), \mathrm{Y}(3+)$, $\mathrm{Ce}(4+)$, and $\mathrm{Nb}(5+)$ ions, a series of $\mathrm{Na}-$ substituted $\mathrm{Na}_{1.9} \mathrm{M}_{0.1} \mathrm{Li}_{2} \mathrm{Ti}_{6} \mathrm{O}_{14}$ materials was prepared [77]. Structural and electrochemical analysis suggests that the substitution of highvalent metals for $\mathrm{Na}+$ can effectively increase the ionic and electronic conductivities of $\mathrm{Na}_{2} \mathrm{Li}_{2} \mathrm{Ti}_{6} \mathrm{O}_{14}$. In [77] concluded that $\mathrm{Na}_{1.9} \mathrm{M}_{0.1} \mathrm{Li}_{2} \mathrm{Ti}_{6} \mathrm{O}_{14}$ is a highly efficient anode material for rechargeable lithium-ion batteries. Diagram of the process of synthesis of $\mathrm{Na}_{1.9} \mathrm{M}_{0.1} \mathrm{Li}_{2} \mathrm{Ti}_{6} \mathrm{O}_{14}$ is shown in Fig.9.

[78] successfully synthesized lithiumtitanate nanotubes (Li-TNTs). The inner and outer diameters of the nanotubes are $5 \mathrm{~nm}$ and
$8 \mathrm{~nm}$ with a distance between the layers at $0.83 \mathrm{~nm}$. Nanotubes correspond to the composition $\mathrm{Li}_{1.81} \mathrm{H}_{0.19} \mathrm{Ti}_{2} \mathrm{O}_{5} \cdot \mathrm{xH}_{2} \mathrm{O}$. The chemical component was $\mathrm{Li}_{1.81} \mathrm{H}_{0.19} \mathrm{Ti}_{2} \mathrm{O}_{5}$ • $\mathrm{H}_{2} \mathrm{O}$, defined as ICP-AES. From the Li-TNT and $\mathrm{WO}_{3}$ nanoparticles thin films $\left(\mathrm{WO}_{3} / \mathrm{Li}\right.$ TNT) were prepared on an ITO glass using a spin coating, and then an electrochromic device was made. The diffusion coefficient of $\mathrm{Li}$ ions in $\mathrm{WO}_{3} / \mathrm{Li}$-TNT film was $6.1 \cdot 10^{-10}$ $\mathrm{cm}^{2} \mathrm{~s}^{-1}$, which is up eight times from the pure WO3 film. The contrast transmittance of pure $\mathrm{WO}_{3}$, based on the ECD (electron capture detector), was $53.3 \%$ at a wavelength of 600 $\mathrm{nm}$. However, this figure increased to $74.1 \%$ 
for $\mathrm{WO}_{3} / \mathrm{Li}-\mathrm{TNT}$. Zinc lithium titanate $\left(\mathrm{Li}_{2} \mathrm{ZnTi}_{3} \mathrm{O}_{8}\right)$ is a desirable anode material for lithium-ion batteries (LIBs) due to its low cost, non-toxicity and high safety. However, low electronic conductivity and limited speed hold back the commercial use of $\mathrm{Li}_{2} \mathrm{ZnTi}_{3} \mathrm{O}_{8}$. An effective strategy was developed in [79] for fabricating an $\mathrm{Li}_{2} \mathrm{ZnTi}_{3} \mathrm{O}_{8}$ electrode using $\mathrm{Cu}$ foils with grown graphene and deposited $\mathrm{Au}$ nanoparticles as a current collector. Note that graphene and $\mathrm{Au}$ nanoparticles can significantly increase the electrical conductivity of the current collector.

The $\mathrm{Cu}$-structured current collector has a rough interface that can enhance adhesion between the $\mathrm{Li}_{2} \mathrm{ZnTi}_{3} \mathrm{O}_{8}$ active material layer and the current collector, providing an excellent electronic transport network and reducing the internal resistance of LIBs. Supported by a $\mathrm{Cu}$ structured current collector, $\mathrm{Li}_{2} \mathrm{ZnTi}_{3} \mathrm{O}_{8}$ shows high storage properties of $\mathrm{Li}+$ with a reversible capacity of $172.2 \mathrm{mAh} /$ $\mathrm{g}$ after 100 cycles at a high current density of 4A / g. Even at $6 \mathrm{~A} / \mathrm{g}$, a value of $148.4 \mathrm{mAh} /$ $\mathrm{g}$ can be achieved. The improved speed of the nanostructured $\mathrm{Li}_{2} \mathrm{ZnTi}_{3} \mathrm{O}_{8}$ electrode makes it a promising anode material for LIBs.

In the [80], an interface element is proposed that allows the liquid / solid electrolyte interface to be analyzed using fourpoint measurements. The functionality of this installation is demonstrated by analyzing the effect of parameter variations at the lithiumlanthanum titanate $\left(\mathrm{Li}_{3 x} \mathrm{La}_{2} /(3-\mathrm{x}) \mathrm{TiO}_{3}, \mathrm{LLTO}\right)$ interface of solid electrolytes used in lithiumair batteries (Lithium-air batteries).

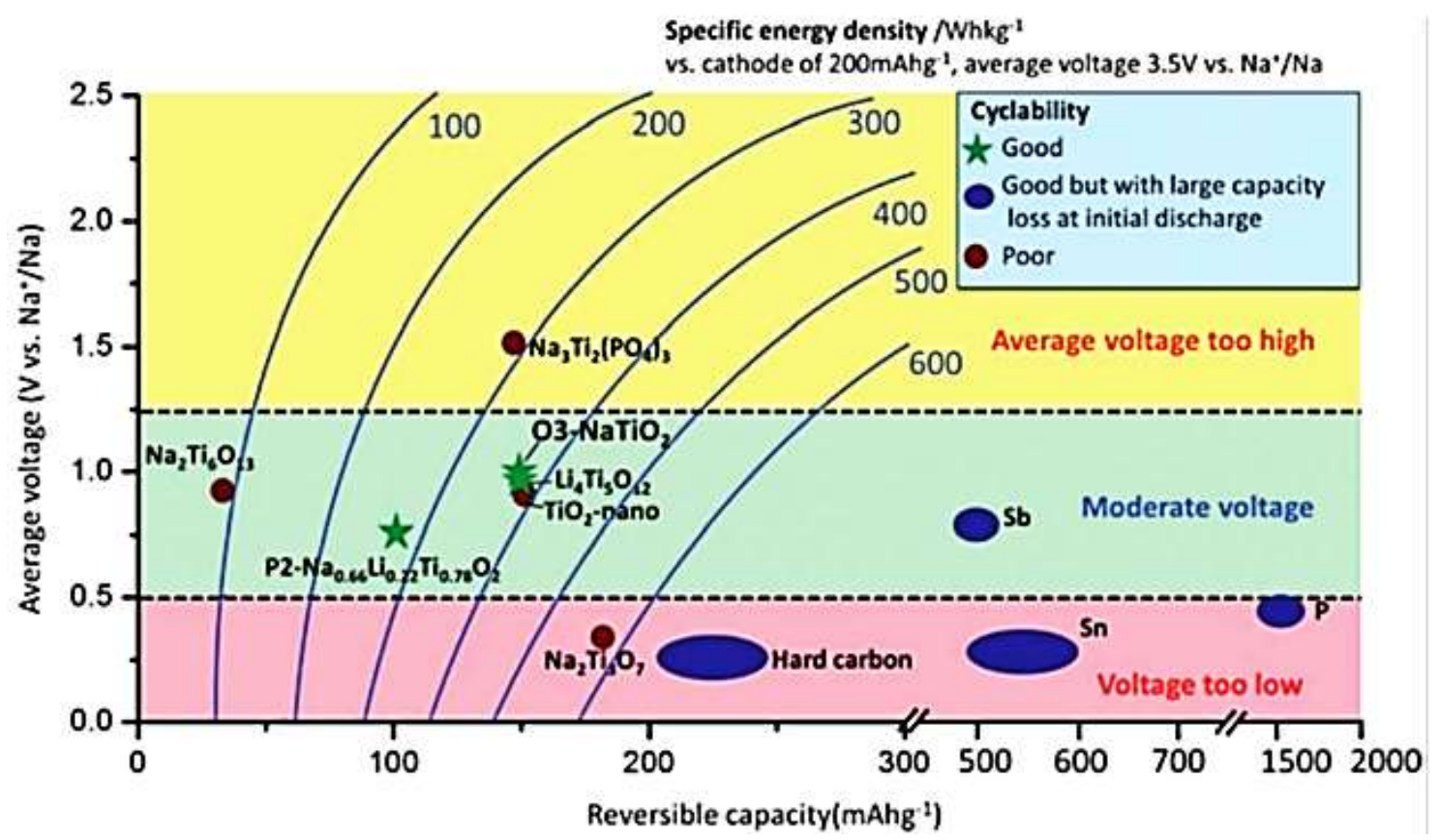

Fig. 10. Dependence of the average voltage on the reversible capacity for various anode materials for sodium and lithium-ion batteries. The lines of constant specific energy density are determined for a cathode with a specific current density of $200 \mathrm{~mA} \mathrm{~h} / \mathrm{g}$ and with an average voltage of $3.5 \mathrm{~V}$ [81.82].

Spinel $\mathrm{Li}_{4} \mathrm{Ti}_{5} \mathrm{O}_{12}$, famous for its zero effect deformation in the course of $\mathrm{Li}$ intercalation, was first investigated as an anode material in a sodium-ion battery in [83]. It revealed that $\mathrm{Li}_{4} \mathrm{Ti}_{5} \mathrm{O}_{12}$ can contain both $\mathrm{Li}^{+}$ ions and $\mathrm{Na}^{+}$ions. $\mathrm{Li}_{4} \mathrm{Ti}_{5} \mathrm{O}_{12}$ electrode with an average potential of about $1.0 \mathrm{~V}$ has a reversible capacity of $145 \mathrm{mAh} / \mathrm{g}$. An atomic scale study of the mechanism of Na storage in $\mathrm{Li}_{4} \mathrm{Ti}_{5} \mathrm{O}_{12}$ was carried out in [84]. Proceeding 
from the functional density theory (DFT), the following mechanism for producing a composite is proposed:

$$
\begin{aligned}
2 \mathrm{Li}_{4} \mathrm{Ti}_{5} \mathrm{O}_{12}+ & \mathrm{Na}^{+}+6 \mathrm{e}^{-} \rightarrow 2 \mathrm{Li}_{7} \mathrm{Ti}_{5} \mathrm{O}_{12}+ \\
& \mathrm{Na}_{6} \mathrm{LiTi}_{5} \mathrm{O}_{12}
\end{aligned}
$$

This mechanism was confirmed by measurements (XRD) and scanning transmission electron microscopy (STEM)
[82]. Average sodium conservation potential is $0.91 \mathrm{~V}$ with a reversible capacity of $155 \mathrm{mAh} /$ $\mathrm{g}$. The dependence of the average voltage on the reversible capacity for different materials of the anode is shown in Fig. 10 from which it follows that the battery with the anode material containing lithium and sodium ions has the best cycleability.

\section{Conclusion}

The analysis of literature data in terms a larger stream of information on the study into lithium and sodium titanates shows that the improvement of synthesis methods and nanostructuring of the phases obtained, development of the theory of modification and functionalization, use of the materials obtained in practice, in particular, the production of lithium and sodium ion batteries, are relevant.

Note that Lithium titanates are promising anode materials for lithium-ion batteries due to their low cost, non-toxicity and high safety.
However, low electronic conductivity and limited ion velocity retard the commercial use of such anodes. Therefore, the synthesis and study of sodium-lithium titanates is highly relevant. Sodium $\mathrm{Na}(+) \quad-$ substituted $\mathrm{Na}_{1.9} \mathrm{M}_{0.1} \mathrm{Li}_{2} \mathrm{Ti}_{6} \mathrm{O}_{14}$ nanoparticles obtained by doping $\mathrm{Na}_{2} \mathrm{Li}_{2} \mathrm{Ti}_{6} \mathrm{O}_{14}$ with $\mathrm{Cu}(2+), \mathrm{Y}(3+), \mathrm{Ce}$ $(4+)$ and $\mathrm{Nb}(5+)$ ions, are characterized by higher electronic and ionic conductivity at relatively low and high temperatures. Also relevant are studies on the functionalization of nanomaterials with bioactive components.

Acknowledgements. This work was carried out with the financial support of the Science Development Foundation under the President of the Republic of Azerbaijan, grant No EIF / MGM / Elm-Tehsil-1-2016-1 (26) -71/05/4

\section{References}

1. Jena B.C., Dresler W., Reilly I.G. Extraction of titanium, vanadium and iron from titanomagnetite deposits at Pipestone Lake, Manitoba, Canada. Minerals Engineering. 1995, vol.8, no. 1-2, pp. 159-168.

2. Reznichenko V.A., Sadyhov G.B., Karyazin I.A. Titanomagnetite - new raw materials for production. Metally. 1997 , no. 6, pp. 3-7. (In Russian)

3. Kelbaliev G.I., Sadyhov F.M., G.M. Mamedov A.N. et al. Theory and practice of granulating powdered materials. Baku: Leman Publ., 326 p. (In Azerbaijan).

4. Kelbaliyev G.I., Mamedov A.N., Gasimova A.M. et al. Modelling of granule formation process of TitanMagnetite powdered materials by the method of rolling. Elixir International
Journal. Materials Science. 2016, vol. 96, pp. 41434-41442.

5. Nan Liu, Xiaoyin Chen, Jinli Zhang, Johannes W. Schwank. A review on $\mathrm{TiO}_{2-}$ based nanotubes synthesized via hydrothermalmethod: Formation mechanism, structure modification, andphotocatalytic applications. Catalysis Today. 2014, vol. 225, pp. 34- 51. DOI: 10.1016/j.cattod.2013.10.090

6. Qi Cheng, Shun Tang, Chang Liu, Qian Lan, Jinxing Zhao, Jiyuan Liang, Feng Wei, Zu-Qi Liu,Yuan-Cheng Cao. Preparation of carbon encapsulated $\mathrm{Li}_{4} \mathrm{Ti}_{5} \mathrm{O}_{12}$ anode material for lithium ion battery through pre-coating method. Ionics. 2017, vol. 23, issue 11, pp. 30313036. DOI: 10.1007/s11581-017-2093-y 
7. Heming_Deng,Wei_Liang, Dexin_Nie, Jian _Wang,Xu_Gao,Shun_Tang,Cui_Liu, and Y uan-Cheng_Cao. High Rate Performance of $\quad \mathrm{Ca}$-Doped $\mathrm{Li}_{4} \mathrm{Ti}_{5} \mathrm{O}_{12}$ Anode Nanomaterial for the Lithium-Ion Batteries. Journal of Nanomaterials. Volume 2018, Article ID 7074824, 6 pages. DOI: 10.1155/2018/7074824

8. Krajewski M., Hamankiewicz B., Michalska M., Andrzejczuk M. Electrochemical properties of lithiumtitanium oxide, modified with $\mathrm{Ag}-\mathrm{Cu}$ particles, as a negative electrode for lithium-ion batteries. RSC Advances, 2017, vol. 7, no. 82, pp. 52151-52164. DOI: $10.1039 / C 7 R A 10608 D$

9. Zima T., Baklanova N., Bataev I. Synthesis and characterization of hybrid nanostructures produced in the presence of the titanium dioxide and bioactive organic substances by hydrothermal method. J. Solid State Chem., 2013, vol. 198, pp. 131-137.

10. Zima T.M., Prosanov I.Yu. Surface Modification of Elongated OneDimensional Titanium Dioxide Structures with Ferromagnetic Nanoparticles. Inorganic Materials, 2016, vol. 52, no. 11, pp. 1160-1165.

11. Van Schalkwijk W. A., Scrosati B. Eds. Advances in Lithium-Ion Batteries; Kluwer Academic /Plenum: New York, 2002.

12. Nazri G.-A., Pistoia, G. Eds. Lithium Batteries: Science and Technology; Kluwer Academic Publishers: New York, 2003.

13. Ozawa K. Ed. Lithium Ion Rechargeable Batteries; Wiley-VCH: Weinheim, Germany, 2009.

14. Alifantis, K E., Hackney S. A., Vasant Kumar R. Eds. High Energy Density Lithium Batteries: Materials, Engineering, Applications; Wiley VCH: Weinheim, Germany, 2010

15. Yaroslavtsev A.B., Kulova T.L., Skundin A.M Electrode nanomaterials for lithiumion batteries. Russ. Chem. Rev., 2015, vol. 84, no.8, pp. 826-852.

16. Reddy M.V., Subba Rao G.V., and
Chowdari B.V.R. Metal oxides and oxysalts as anode materials for $\mathrm{Li}$ ion batteries. Chem. Rev., 2013, vol. 113, p. 5364.

17. Kleykamp H. Phase equilibria in the LiTi-O system and physical properties of $\mathrm{Li}_{2} \mathrm{TiO}_{3}$. Fusion Engineering and Design. 2002, 61-62, pp. 361-366.

18. Stenina, A.B. Il'in, A.B. Yaroslavtsev. Synthesis and Ionic Conductivity of $\mathrm{Li}_{4} \mathrm{Ti}_{5} \mathrm{O}_{12}$. Inorganic Materials, 2015, vol. 51, no. 1, pp. 62-67.

19. Chen C.H., Vaughey J.T., Jansen A.N., Dees D.W., Kahaian A.J., Goacher T., and Thackeray M.M. Studies of $\mathrm{Mg}$ substituted $\mathrm{Li}_{4-}{ } \mathrm{MgxTi}_{5} \mathrm{Oi}_{2}$ spinel electrodes $(0<x<1)$ for lithium batteries. $J$. Electrochem. Soc., 2001, vol. 148, pp. A102-A104.

20. Wilkening M., Amade R., Iwaniak W., and Heitjans P. Ultraslow Li diffusion in spinel-type structured $\mathrm{Li}_{4} \mathrm{Ti}_{5} \mathrm{O}_{2} . \quad \mathrm{A}$ comparison of results from solid state NMR and impedance spectroscopy. Phys. Chem. Chem. Phys., 2007, vol. 9, pp. 1239-1246.

21. Su L, Jing Y, Zhou Z. Li ion battery materials with core-shell nanostructures. Nanoscale. 2011 Oct 5; 3(10):3967-83. Epub 2011 Aug 30.

22. Hao Y., Lai Q., Xu Z., Liu X., and Ji X. Synthesis by TEA sol-gel method and electrochemical properties of $\mathrm{Li}_{4}+$ ${ }_{x} \mathrm{Ti}_{5} \mathrm{O}_{12}$ anode material for lithium-ion battery. Solid State Ionics. 2005, vol. 176, pp. 1201-1206.

23. Pechini M.P. Method of Preparing Lead and Alkaline Earth Titanates and Niobates and Coating Method Using the Same to Form a Capacitor: US Patent 333069. 196711 July.

24. Gu H., Ran R., Zhou W., Shao Z. AnodeSupported ScSZ-Electrolyte SOFC with Whole Cell Materials from Combined EDTA-Citrate Complexing Synthesis Process /I). Power Sources. 2007, vol. 172, pp. 704-712.

25. Qi Cheng, Shun Tang, Chang Liu, Qian Lan. Preparation and electrochemical performance of $\mathrm{Li}_{4-\mathrm{x}} \mathrm{Mg}_{\mathrm{x}} \mathrm{Ti}_{5} \mathrm{O}_{12}$ as anode 
materials for lithium-ion battery. Journal of Alloys and Compounds, 2017, vol. 722, pp. 229-234,

DOI: 10.1016/j.jallcom.2017.06.040

26. Lin, Zh.-Yu, Hsu Chao-Chia, Ho HsinPing, and $\mathrm{Wu}$ She-Huang. Sol-gel synthesis of aluminum doped lithium titanate anode material for lithium ion batteries. Electrochim. Acta, 2013, vol. 87, pp. $126-132$.

27. Li X., Qu M., Huai Y, and Yu Z. Preparation and electrochemical performance of $\mathrm{Li}_{4} \mathrm{Ti}_{5} \mathrm{O}_{12} /$ car- bon/carbon nano-tubes for lithium ion battery. Electrochim. Acta, 2010, vol. 55, pp. 2978-2982.

28. Zhao E., Qin C., Jung H.R. et al. Lithium Titanate Confined in Carbon Nanopores for Asymmetric Supercapacitors. ACS Nano. 2016 Apr 26; vol. 10, no. 4, pp. 3977-84. DOI: 10.1021/acsnano.6b00479

29. Hernández-Hipólito P., García-Castillejos M., Martínez-Klimova E., Juárez- Flores N., Gómez-Cortés A., Klimova T.E. Biodiesel production with nanotubular sodium titanate as a catalyst. Catal. Today. 2014, vol. 220-222, pp. 4-11. DOI:10.1016/j.cattod.2013.09.003.

30. Chen H.Y., Lo S.L., Ou H.H. Catalytic hydrogenation of nitrate on $\mathrm{Cu}-\mathrm{Pd}$ supported on titanate nanotube and the experiment after aging, sulfide fouling and regeneration procedures. Appl.Catal. B. 2013, vol. 142-14, pp. 65-71.

DOI: 10.1016/j.apcatb.2013.05.004.

31. Kordás K., Mohl M., Kónya Z., Kukovecz A. Layered titanates nanostructures: perspectives for industrial exploitation. Trans. Mater. Res. 2015, vol.2, no.1, p. 015003, DOI: $\quad 10.1088 / 2053$ 1613/2/1/015003

32. Matos B.R., Santiago E.I., Rey J.F.Q., Ferlauto A.S. Nafion-based composite electrolytes for proton exchange membrane fuel cells operating above 120 _C with titania nanoparticles and nanotubes as fillers. Power Sources. 2011, vol.196, pp. 1061-1068. DOI: 10.1016/j. jpowsour.2010.08.025

33. Wang L., Liu W., Wang T., Ni J. Highly efficient adsorption of $\mathrm{Cr}(\mathrm{VI})$ from aqueous solutions by aminofunctionalized titanate nanotubes. Chem. Eng. J. 2013, vol. 225, pp. 153-163. DOI: 10.1016/j.cej.2013.03.081

34. Ai Q, YangD., LiY., ShiJ. Highly efficient covalent immobilization of catalase on titanate nanotubes. Biochem. Eng. J. 2014, vol. 83, pp. 8-15.

DOI: $10.1016 /$ j.bej.2013.11.021.

35. Tsai C-C., Teng H. Regulation of the physical characteristics of titania nanotube aggregates synthesized from hydrothermal treatment. Chem. Mater. 2004, vol. 16, pp. 4352-4358.

36. Wang Y.Q., Hu G.Q., Duan X.F., et al. Microstructure and formation mechanism of titanium dioxide nanotubes. Chem. Phys. Lett. 2002, vol. 365, pp. 427-431.

37. Kharissova O.V., Kharisov B.I., Ortiz Méndez U. Microwave-assisted synthesis of coordination and organometallic compounds, in: S. Grundas (Ed.) / Advances in Induction and Microwave Heating of Mineral and Organic Materials, InTech, 2011, DOI: 10.5772/13149

38. Peng Y.P., Lo S.L., Ou H.H., et al. Microwave-assisted hydrothermal synthesis of $\mathrm{N}$-doped titanate nanotubes for visible-light-responsive photocatalysts. J. Hazard. Mater. 2010, vol. 183, pp. 754-758. $\quad$ DOI: $10.1016 / \mathrm{j}$. jhazmat.2010.07.090

39. Sikhwivhilu L.M., Mpelane S., Moloto N., Ray S. Hydrothermal synthesis of $\mathrm{TiO} 2$ nanotubes; microwave heating versus conventional heating, in: S. Mathur, S.S. Ray, T. Ohji (Eds.), Nanostructured Materials and Nanotechnology IV: Ceramic Engineering and Science Proceedings, 31, John Wiley \& Sons, Inc., Hoboken, NJ, 2010, pp. 45-49, DOI: 10.1002/9780470944042.ch6.

40. Ou H.H., Lo S.L., Liao C.H.N-doped $\mathrm{TiO}_{2}$ prepared from microwave-assisted titanatenanotubes $\left(\mathrm{Na}_{\mathrm{x}} \mathrm{H}_{2-\mathrm{x}} \mathrm{Ti}_{3} \mathrm{O}_{7}\right)$ : the effect of microwave irradiation during TNT synthesis on the visible light photoactivity of N-doped TiO2. J. Phys. Chem. C. 2011, vol. 115, pp. 4000-4007. 
DOI: 10.1021/jp1076005.

41. Ribbens S., Meynen V., Van Tendeloo G., $\mathrm{Ke}$ X. Development of photocatalytic efficient Ti-based nanotubes and nanoribbons by conventional and microwave assisted synthesis strategies. Microporous Mesoporous Mater. 2008, vol.114, pp. 401-409. DOI: 10.1016/j.micromeso.2008.01.028.

42. Manfroi D.C., A. dos Anjos, Cavalheiro A.A., Perazolli L.A. Titanate nanotubes produced from microwave-assisted hydrothermal synthesis: photocatalytic and structural properties. Ceram. Int. 2014, vol. 40, 2014, pp. 14483-14491.

43. Silviu Preda, Melita Rutar, Polona Umek, Maria Zaharescu. A study of thermal properties of sodium titanate nanotubes synthesized by microwave-assisted hydrothermal method. Materials Research Bulletin. 2015, vol. 71, pp. 98105.

44. Limmer S.J., Cao G. Nanorods, Nanotubes, and Nanomaterials Research Progress. AdV. Mater. 2003, vol. 15, p. 427.

45. Lee K., Yoo D. Large-Area Sodium Titanate Nanorods Formed On Titanium Surface Via $\mathrm{NaOH}$ Alkali Treatment. Archives of Metallurgy and Materials. 2015, vol. 60, no. 2, pp. 1371-1374.

46. Tang J., Redl F., Zhu Y. et al. An organometallic synthesis of $\mathrm{TiO}_{2}$ nanoparticles. Nano Letters. 2005, vol. 5, no. 3, pp. 543-548.

47. Zhang Z., Zhong X., Liu S. et al. Aminolysis route to monodisperse titaniananorods with tunable aspect ratio. Angewandte Chemie International Edition. 2005, vol. 44, no. 22, pp. 34663470.

48. Pradhan S.K., Reucroft P.J., Yang F., Dozier A. Growth of $\mathrm{TiO}_{2}$ nanorods by met alorganic chemical vapor deposition. J. Crystal Growth, 2003, vol. 256, pp. 8388.

49. Lei Y., Zhang L.D., Fan J. C. Fabrication, characterization and Raman study of $\mathrm{TiO}_{2}$ nanowire array prepared by anodic oxidative hydrolysis of $\mathrm{TiCl}_{3}$. Chem. Phys. Lett. 2001, vol. 338, p. 231.

50. Zhu Y., Li H., KoltypinY., et al. Sonochemical synthesis of titania whiskers and nanotubes. Chem. Commun. 2001, no. 24, p. 2616.

51. Wei Kong, Bo Liu, Bo Ye., et al. An Experimental Study on the Shape Changes of $\mathrm{TiO}_{2}$ Nanocrystals Synthesized by Microemulsion-Solvothermal Method. Journal of Nanomaterials. Vol. 2011. Article ID 467083, 6p.

52. Weng C.-C., Chen C.-P., Ting C.-H., et al. Using a solution crystal growth method to grow arrays of aligned, individually distinct, single-crystalline $\mathrm{TiO}_{2}$ nano needles within nanocavities. Chemistry of Materials, 2005, vol. 17, no. 13, pp. 3328-3330.

53. Kolenko Y.V., Kovnir K.A., A. I. Gavrilov A.I., et al. Hydrothermal Synthesis and Characterization of Nanorods of Various Titanates and Titanium Dioxide. J. Phys. Chem. B, 2006, vol. 110, pp. 4030-4038.

54. Byrappa K., Yoshimura M. /Handbook of Hydrothermal Technology; William Andrew Publishing: New York, 2001. Chapter 1.

55. Zhang Y. X., Li G.H., Jin Y. X., et al. Hydrothermal synthesis and photoluminescence of $\mathrm{TiO}_{2}$ nanowires. Chem. Phys. Lett. 2002, vol. 365, p. 300.

56. Sun X., Li Y. Optimization of the Alkaline Hydrothermal Route to Titanate Nanotubes. Chem.Eur. J. 2003, vol. 9, p. 2229.

57. Viana B.C., Ferreira P.O., Filho A.G.S., et al. Highlighting the mechanisms of the titanate nanotubes to titanate nanoribbons transformation. J. Nanopart. Res. 2011, vol. 13, pp. 3259-3265.

58. Xu Y., Bauer D., Lübke M., Ashton T.E., Zong Y., Darr J.A. High-power sodium titanate anodes; a comparison of lithium vs sodium-ion batteries. Journal of Power Sources. 2018, vol. 408, pp. 2837. DOI:10.1016/j.jpowsour.2018.10.038.

59. Lee K., Yoo D. Large-Area Sodium Titanate Nanorods Formed on Titanium 
Surface Via $\mathrm{NaOH}$ Alkali Treatment. Archives of Metallurgy and Materials. 2015, vol. 60, no. 2, pp. 1371-1374.

60. Yao L., He J., Li T., Ren T. Novel $\mathrm{SiO}_{2} / \mathrm{H}_{2} \mathrm{Ti}_{2} \mathrm{O}_{5} \cdot \mathrm{H}_{2} \mathrm{O}-\mathrm{Nanochain}$ Composite with High UV-Visible Photocatalytic Activity for Supertransparent Multifunctional Thin Films. Langmuir. 2016, vol. 32, pp. 13611-13619.

61. Zhu X., Hitchcock A.P., Bittencourt C., et al. Individual Titanate Nanoribbons Studied by 3D-Resolved Polarization Dependent X-ray Absorption Spectra Measured with Scanning Transmission Xray Microscopy. The Journal of Physical Chemistry C, 2015, vol. 119, no. 42, pp. 24192-24200.

62. Anitha V.C., Banerjee A.N., Joo S.W., et al. Morphology-dependent low macroscopic field emission properties of titania/titanatenanorods synthesized by alkali-controlled hydrothermal treatment of a metallic $\mathrm{Ti}$ surface. Nanotechnology, 2015, vol. 26, no. 35, pp. 1-9.

63. Zhou Qian, Liu Li, Tan Jinli, Yan Zichao, Huang Zhifeng, Wang Xianyou. Synthesis of lithium titanatenanorods as anode materials for lithium and sodium ion batteries with superior electrochemical performance. Journal of Power Sources. 2016, vol. 283, pp. 243-250.

64. Florentina Maxim, Daniela Berger, FlorinaTeodorescu, Hornoiu, Cecilia Lete, Speranta Tanasescu. Low-Temperature Synthesis and Thermodynamic and Electrical Properties of Barium Titanate Nanorods. Journal of Nanomaterials. 2015, Article ID $827641,10 \mathrm{p}$.

65. Venkatesan K.A., Sukumaran V., Antony M.P., et al. Studies on feasibility of using crystalline silicotitanates. J. Radioanal. Nucl. Chem. 2009, vol. 280, pp. 129-136.

66. Yang D., Sarina S., Zhu H. et al. Design of Chitosan-Grafted Carbon Nanotubes: Evaluation of How the $-\mathrm{OH}$ Functional Group Affects $\mathrm{Cs}^{+}$Adsorption. Angew. Chem. Int. Ed. 2011, vol. 50, pp. 10594 10598.
67. Yang D., Zheng Z., Liu H. et al. Phase Transition between Nanostructures of Titanate and solutions. Phys. Chem. Chem. Phys. 2010, vol. 12, pp. 1271 1277.

68. Amna T., Hassan M.S. et al. Characterization and potent bactericidal effect of cobalt doped titanium dioxide nanofibers. Ceram. Int., 2013, vol. 39, pp. 3189-3193.

69. Yada M., Goto Y., Uota M., Torikai T. and Watari $T$. Layered sodium titanate nanofiber and microsphere synthesized from peroxotitanic acid solution. J. Eur. Ceram. Soc., 2006, vol. 26, no.4-5, pp. 673-678.

70. Becker I., Hofmann I., Muller F. A. Preparation of bioactive sodium titanate ceramics. Journal of the European Ceramic Society. 2007, vol. 27, pp. 45474553.

71. Alaboina P.K., Ge Y, Uddin Md-J. et al. Nanoscale Porous Lithium Titanate Anode for Superior High Temperature Performance. ACS Appl Mater Interfaces. 2016, vol. 8, no. 19, pp. 1212733.

72. Lin X., Li P., Shao L. Shui M. et al. Lithium barium titanate:A stable lithium storage material for lithium-ion batteries. Journal of Power Sources. 2015, vol. 278, pp. 546-554.

73. Plachy T., Mrlik M., Kozakova Z., Suly P., Sedlacik M., Pavlinek V., Kuritka I. The electrorheological behavior of suspensions based on molten-salt synthesized lithium titanate nanoparticles and their core-shell titanate/urea analogue. ACS Appl Mater Interfaces. 2015, vol. 7, no. 6, pp. 3725-31.

74. Labke Mechthild, Marchand Peter, Brett Dan J. L., Shearing Paul, Gruar Robert, Liu Zhaolin, Darr Jawwad A. High power layered titanate nano-sheets as pseudo capacitive lithium-ion battery anodes. Journal of Power Sources. 2016, vol. 305, pp. 115-121.

75. Chen Kebin, Yu Zhiqiang, Deng Shawn, Wu Qiang, Zou Jianxin, Zeng Xiaoqin. Evaluation of the low temperature 
76. performance of lithium manganese oxide/lithium titanate lithium-ion batteries for start/stop applications. Journal of Power Sources. 2015, vol. 278, pp. 411419.

77. Lakshmi D., Nalini B., Abhilash K.P., Selvin P. Christopher. Accomplishment of highly porous-lithium lanthanum titanate through microwave treatment AIP Conference Proceedings. 2016, vol. 1731, no.1, id.050079.

78. Wang P., Qian S., Yi T.F., Yu H., Yan L., Li P., Lin X., Shui M., Shu J. Effect of Sodium-Site Doping on Enhancing the Lithium Storage Performance of Sodium Lithium Titanate. ACS Appl Mater Interfaces. 2016, vol. 8, no. 16, pp. 1030214. DOI: 10.1021/acsami.6b01293.

79. Dong Yunbing, Xiong Chunrong, Zhang Yilu, Xing Shuai, Jiang Hong. Lithiumtitanate-nanotube-supported $\quad \mathrm{WO}_{3}$ for enhancing transmittance contrast in electrochromics. Nanotechnology. 2016, vol. 27 , issue 10, article id. 105704.

80. Li Xinxi, Wang Lijuan, Li Chengfei, Chen Baokuan, Zhao Qiang, Zhang Guoqing. Rational design of highrate lithium zinc titanate anode electrode by modifying $\mathrm{Cu}$ current collector with graphene and Au nanoparticles. Journal of Power Sources. 2016, vol. 308, pp. 65-74.

81. Uhlmann C., Braun P., Illig J., Weber A., Ivers-Tiffée E. Interface and grain boundary resistance of a lithium lanthanum titanate $\left(\mathrm{Li}_{3 \mathrm{x}} \mathrm{La}_{2 / 3-\mathrm{x}} \mathrm{TiO}_{3}\right.$, LLTO) solid electrolyte. Journal of Power Sources. 2016, vol. 307, pp. 578-586.

82. $\mathrm{Wu}$ D., Li X., Xu B. et all. $\mathrm{NaTiO}_{2}$ : a layered anode material for sodium-ion batteries. Energy Environ. Sci. 2015, vol.8, no.1, pp. 195-202.

83. Mei Y., Huang Y., Hu X. Cycleability of battery with anode material containing lithium and sodium ions. J. Mater. Chem. A., 2016, 4, pp. 12001-1213.

84. Zhao L., Pan H.L., Hu Y.S. et a. Lithium Storage in $\mathrm{Li}_{4} \mathrm{Ti}_{5} \mathrm{O}_{12}$ Spinel: The Full Static Picture from Electron Microscopy. Chin. Phys. B., 2012, vol. 24, pp. 32333238

85. Sun Y., Zhao L., Pan P.H. et al. Direct Atomic-scale study of the storage mechanism of $\mathrm{Na}$ in $\mathrm{Li}_{4} \mathrm{Ti}_{5} \mathrm{O}_{12}$. Nat. Commun. 2013, vol. 4, article number: 1870.

\title{
ПОЛУЧЕНИЕ И ИСЛЕДОВАНИЕ ФУНКЦИОНАЛЬНЫХ СВОЙСТВ НАНОСТРУКТУРИРОВАННЫХ ТИТАНАТОВ ЛИТИЯ И НАТРИЯ
}

\author{
А.Н. Мамедов ${ }^{1,2}$, У.Н. Шарифова ${ }^{1}$ Г.М. Самедзаде ${ }^{1}$, А.М. Гасымова ${ }^{1}$, С.А. Гулиева ${ }^{3}$ \\ ${ }^{1}$ Институт Катализа и Неорганической Химии Национальной АН Азербайджана, \\ AZ 1143 Баку, пр. Г. Джавида, 113, e-mail: asif.mammadov.47@mail.ru \\ ${ }^{2}$ Азербайджанский Технический Университет \\ AZ 1073 Баку, пр. Г. Джсавида, 107 \\ ${ }^{3}$ Азербайджанский Государственный Педагогический Университет \\ AZ 1000 Баку, ул. У. Гаджибейли, 68
}

\begin{abstract}
Проанализированы и обобщены имеющиеся в литературе сведения о способах получения, структуре и физико-химических свойствах наноструктурированных материалов на основе титанатов лития $u$ натрия. Рассмотрены композитные наноструктурированные функииональные материаль на основе титанатов лития и натрия для получения анодного материала с высокой емкостью, стабильностью рабочего потенциала в ходе ичиклирования, $c$ оптимальной электронной и ионной проводимостью. Представлены примеры с конкретными схемами, физико-химическими данными и механизмами функциональных процессов при использовании биоактивных и легирующих компонентов.
\end{abstract}

Ключевые слова: титанаты лития и натрия, функционализация, наноструктурирование, ионные бamapeu 


\title{
NANOSTRUKTURLAȘMIȘ LITIUM VO NATRIUM TITANATLARININ ALINMASI VӘ FUNKSIONAL XASSOLORININ TODQIQI
}

\author{
A.N. Məmmədov ${ }^{1,2}$, Ü.N. Şərifova ${ }^{1}$, Q.M. Səmədzado ${ }^{1}$, A.M. Qasımova ${ }^{1}$, S. O. Quliyeva ${ }^{3}$ \\ ${ }^{1}$ AMEA akademik M.Nağlyev adına Kataliz və Qeyri-üzvi Kimya Institutu \\ AZ 1143 Bakl, H.Cavid pr.113, e-mail: asif.mammadov.47@mail.ru \\ ${ }^{2}$ Azarbaycan Texniki Universiteti \\ AZ 1073 Bakl, H.Cavid pr.107 \\ ${ }^{3}$ Azarbaycan Dövlat Pedaqoji Universiteti \\ AZ 1000, Bakl, Ü.Hacıbəylu küç.68
}

Litium və natrium titanatlarına ssaslanan nanostrukturlu materialların sintez üsulları, quruluşu və fizikikimyəvi xüsusiyyatlari haqqında adəbiyyat malumatları təhlil edilmiş va ümumilașdirilmișdir. Optimal electron va ion keçiriciliyina, yüksək tutuma, tsikl zamanı sabit işçi potensiala malik ion batareyalarında anod kimi istifado etmək üçün natrium vo litium titanatlartna osaslanan funksional nanostrukturlu perspektiv kompozit materiallar haqqinda geniş malumat verilmişdir. Bioaktiv komponentlar vo heterovalentli kationlarla legirlamənin fiziki-kimyəvi xüsusiyyatlari vo funksional proseslarin mexanizminin sxemlari taqdim edilmişdir.

Açar sözlor: litium və natrium titanatları, funksiyalaşma, nanostrukturlaşma, ion batareyaları 